\title{
Correction to: The devil is in the details: Capital stock estimation and aggregate productivity growth-An application to the Spanish economy
}

\author{
Francisco-Javier Escribá-Pérez ${ }^{1} \cdot$ María-José Murgui-García ${ }^{1}$. \\ José-Ramón Ruiz-Tamarit ${ }^{1,2}$
}

Published online: 29 October 2021

(c) ISEG - Instituto Superior de Economia e Gestão 2021

\section{Correction to: Portuguese Economic Journal https://doi.org/10.1007/s10258-020-00187-z}

Firstly, regarding the reference to the equations, Eq. (10) is mentioned several times in Sect. 2, where it should be Eq. (3) instead.

Besides, the same mistake happens regarding equations (A.1), (A.2) and (A.3), all appearing in the text whereas Eq. (8), (9) and (10) should be mentioned at their place.

The original article is corrected.

Publisher's Note Springer Nature remains neutral with regard to jurisdictional claims in published maps and institutional affiliations.

The original article can be found online at https://doi.org/10.1007/s10258-020-00187-z.

María-José Murgui-García

maria.j.murgui@uv.es

José-Ramón Ruiz-Tamarit

ramon.ruiz@uv.es

1 Department of Economic Analysis, Universitat de València, Av. dels Tarongers s/n, 46022 València, Spain

2 Department of Economics IRES, Université Catholique de Louvain, Ottignies-Louvain-la-Neuve, Belgium 